\title{
Post-Traumatic Responses in the War Narratives of Hanan al- Shaykh's The Story of Zahra and Chimamanda Ngozi Adichie's Half of a Yellow Sun
}

Majda R. Atieh and Ghada Mohammad

Abstract

This chapter extends the focus of wartime trauma scholarship to recognise female non-combatants' variants of traumatic victimisation and agency, as presented in the Middle Eastern and African contexts. The agency of such actors, who suffered tragically from the traumas of war, was inexplicably overlooked in both Middle Eastern and African literatures and scholarships. Thus, my chapter rectifies this lacuna and presents the significant contributions of two female authors, Hanan alShaykh and Chimamanda Ngozi Adichie, and examines the post-traumatic responses of female non-combatants in the war narratives of al-Shaykh's The Story of Zahra and Adichie's Half of a Yellow Sun. In particular, I readdress The Story of Zahra in light of Half of a Yellow Sun that revises the role of traumatised female non-combatants in collective change. I contend that reading traumas in both narratives propounds that traumatic recovery is never complete. However, the impossibility of transcending the 'acting-out' of trauma does not necessarily entail the impossibility of the 'working-through.' Arguably, traumatised victims may fail to entirely disengage themselves from the traumatic past but they can still be agents of change. As such, Half of a Yellow Sun exposes the limitation and the failure of The Story of Zahra's traumatised non-combatant in realising any social transformation. On the other hand, I demonstrate how both narratives construe narration and scriptotherapy, as modes of re-enactment, in relation to the inculcation of self-reconstruction and instigation of individual and collective change. My argument follows an interdisciplinary approach as it engages cultural studies, psychoanalysis and narratology in addressing trauma. Also, trauma theories by Van der Kolk, Dori Laub, Suzette Henke and Cathy Caruth are of substantial significance to this proposed reading.

Key Words: War trauma, post-traumatic response, female non-combatant, 'working-through,' 'acting-out,' narration, scriptotherapy, agency. $* * * * *$

\section{Introduction}

Wartime trauma literature and scholarship reveal an exclusive focus on the masculine response to combat, which either effaces or subordinates and synchronises the female reaction to war with the male-dominated collective response. Though some narratives by Middle Eastern and African female writers have actually highlighted the peripheral actors in times of war, namely victimised Post-Traumatic Responses in the War Narratives

218

female non-combatants and their suffering from war trauma, they do not suggest any therapeutic response. Rectifying this lacuna, my chapter proposes a contribution to the wartime trauma scholarship by addressing women's attempt at agency and initiation of healing. As such, traumatic responses of two female noncombatants in Middle Eastern and African war narratives, The Story of Zahra by Hanan al-Shaykh on the Lebanese Civil War (1975-1990) and Half of a Yellow Sun by Chimamanda Ngozi Adichie on Nigeria-Biafra War (1967-1970), are explored. Reading war trauma in both narratives reveals that the impossibility of transcending the 'acting-out' of trauma does not entail the impossibility of the 'working-through.' Traumatised victims may fail to entirely disengage themselves from the past, but they can still be agents of change. Exploring the victimised females' attempts at agency in both narratives revises the role of traumatised individuals in collective change. In particular, reading al-Shaykh's narrative in light of Half of a Yellow Sun suggests a varied translation of the relationship 
between victimhood and agency. Such translation proposes a revised definition of victimhood, where potential involvement of traumatized victims in the collective change is made possible.

\section{Traumatic Symptoms: Victimised Female Non-Combatants in The Story of} Zahra and Half of a Yellow Sun

Addressing the experience of female non-combatants during war, both Story of

Zahra and Half of a Yellow Sun evolve as significant modes of war trauma narratives. Story of Zahra presents a mode of individual trauma, namely pre-war childhood trauma where Zahra, a Lebanese female, experiences domestic violence, alienation from the mother, gender discrimination, and sexual abuse. However, Zahra's traumatic symptoms are all complicated by the escalation of the Civil War. In Half of a Yellow Sun, witnessing the Biafran Civil War's atrocities precipitates a collective trauma as several female and male civilians undergo fear and hunger. For instance, Olanna, a female professor at Nsukka University in the Igboland, witnesses the murder of the Igbo people, including her relatives, around their compound in Kano. Kainene, Olanna's twin sister, undergoes a similar traumatic encounter when, in a very horrifying scene, she observes the tragic death of her steward.

Both narratives feature traumatic memories that develop as intrusive recollections, haunting flashbacks, somatic sensations, and other signs. Relating the long term outcome of trauma to the initial somatic response, Van der Kolk observes that 'traumatized people keep experiencing life as a continuation of the trauma, and remain in a state of constant alert for its return.' 1 In this respect, alShaykh's narrative presents a disturbing memory that retrieves early childhood's images of intense fear, such as a frightened little girl and a mother 'trembling behind the door' 2 hiding from a male chaser, and continues to haunt Zahra whenever under stress. In the same way, Adichie's narrative features traumatic Majda R. Atieh and Ghada Mohammad

\section{9}

memories and images that continue to evolve and haunt Olanna's life. For instance, the image of plaited hair resting in a calabash revisits her whenever she plaits the hair of Baby, the daughter of her revolutionary lover, Odenigbo. Olanna's ability of visualisation even becomes dulled by disturbing memories about victimised relatives, such as Arize, Aunty Ifeka, and Uncle Mbaezi.

The traumatic signs in both narratives develop into the dissociative inability of communicating trauma. Asserting the limitation of language in communicating trauma, psychoanalyst Dori Laub contends that 'there are never enough words or the right words [...] to articulate the story that cannot be fully captured in thought, memory, and speech.'3 In Adichie's narrative, such linguistic limitation is translated into an initial failure of narration. Olanna encounters difficulty verbalising what she has been through and loses the ability to narrate her trauma to the others. Olanna's verbal failure develops into spatial dissociation that involves her loss of touch with the surroundings and with sense of time, and her failure to engage in the present. In al-Shaykh's narrative, Zahra is presented as being incapable of exerting any counteracting power against forces manipulating her life. She is always portrayed as seeking a voice and feeling like crying out and screaming. Zahra's verbal failure also develops into spatial dissociation and withdrawal. She retreats into her 'shell' perpetuating the standardised image the others held of her. She recites: 'I am at my wits' end, and am annoyed with myself and hate myself because I stay silent. When will my soul cry out like a woman surrendering to a redeeming love?'4

\section{Defining Agency in Story of Zahra and Half of A Yellow Sun}

Cross-cultural trauma studies reveal that the manifestation of distress varies according to cultural differences. For instance, critics George F. Rhoades and Vedat Sar present an international look at the similarities and differences of longlasting 
trauma. They suggest that the reaction to trauma can be 'unique according to a person's culture and similar in aspects to the experiences of others around the world.' 5 In light of this cultural perspective, examining trauma in both narratives reveals that while haunting memories, silence, and dissociation are common traumatic reactions, adaptation to trauma is different. However, such difference is not culturally motivated as will be demonstrated throughout this reading. 'Acting-out' and 'working through' are two strategies of agency that define female resistance and healing from the reoccurrence of traumatic memory in alShaykh's and Adichie's narratives respectively. These two strategies are identified in Freudian psychoanalysis and developed by Dominick LaCapra for the purpose of historical studies. For LaCapra, the emotional response of the historian to events involves one of two extremes: the 'full identification' 6 that leads to the 'acting out,' or the 'pure objectification' 7 that leads to the 'working through.' Applying such understanding of these two strategies to al-Shaykh's and Adichie's narratives articulates a subversive reading that contests all previous interpretations of alPostTraumatic Responses in the War Narratives

\section{0}

Shaykh's narrative. Such critical studies have contributed to the construction of a passive definition of victimhood by projecting Zahra's helplessness as an utter obstacle to initiating agency. Accentuating the direness of Zahra's traumatised past, scholars discern no potential for a possible development of victimhood into agency. Such scholarship has constructed a paratext that controls the reception of al-Shaykh's narrative as an account of traumatic submissiveness. However, identifying the responses of the traumatised females in Adichie's narrative invites a different understanding of Zahra's victimhood.

In Half of a Yellow Sun, survival from trauma is initiated by breaking the victim's traumatic dissociation. Such break involves establishing an alternative dissociation from trauma itself. In this context, LaCapra contends that it is the 'working-through' strategy that enables the victim 'to gain critical distance on a problem,' 8 and 'to distinguish between past, present and future.'9 In Adichie's narrative, dissociation from trauma develops from the reverse articulation of verbal or written testimony to an empathetic listener or reader, which has a therapeutic function. In Freudian terminology, such kind of testimony or storytelling is called 'talking cure.' For psychiatrist and author Judith Herman, the talking cure offers 'relief of many of the major symptoms of post-traumatic stress disorder.' 10 Testimony helps the victim release unconscious emotions and tensions after recalling and reliving the traumatic experience. Such emotional release is therapeutic as it integrates all fragmented images and enables the individual to recover lost details and have a full understanding of his/her experience. In Adichie's narrative, Olanna, upon returning home from Kano, tells Odenigbo about the horror she witnessed. She describes 'the vaguely familiar clothes on the headless bodies in the yard, the still-twitchy fingers on Uncle Mbaezi's hand, the rolled-back eyes of the child's head in the calabash.' 11 Using Dori Laub's terms, Odenigbo functions here as the 'addressable other' who 'can hear the anguish of one's memories and thus affirm and recognize their realness.' 12 Scriptotherapy is an equally important written mode of dissociative re-enactment, which initiates Olanna's agency and survival. Scriptotherapy is defined by Suzette Henke as the 'process of writing out and writing through traumatic experience in the mode of therapeutic reenactment.' 13 Such kind of process relies on 'the artistic replication of a coherent subject-position' 14 to generate 'a healing narrative that temporarily restores the fragmented self to an empowered position of psychological agency.' 15 In Adichie's narrative, Olanna powerfully detaches herself from trauma through recounting her victimisation to Ugwu, Odenigbo's houseboy, who functions as the male scriptwriter:

Ugwu was writing as she spoke, and his writing, the earnestness 
of his interest, suddenly made her story important, made it serve a larger purpose that even she was not sure of, and so she told Majda R. Atieh and Ghada Mohammad

221

him all she remembered about the train full of people who had

cried and shouted and urinated on themselves. 16

On the contrary, in al-Shaykh's narrative, Zahra seeks survival through silence and isolation, which further extend traumatic dissociation. Psychoanalyst Laub highlights the necessity of testimony for survival. She asserts that the survivors 'did not only need to survive so that they could tell their story; they also needed to tell their stories in order to survive.'17 In al-Shaykh's narrative, had Zahra sought therapeutic connection through verbal communication, she would have found it. While contending that the development of victimhood into healing and agency on Zahra's part is possible, I am not ignoring the socio-cultural constraints on the individual. In fact, the limitation of healing mechanisms in a conservative Islamic environment is fully recognisable. Nonetheless, Zahra's major flaw is that she does not utilise the possible social mechanisms yielded by another culture. Arguably, she could have profited from being in Africa, where narration to a compassionate listener like her uncle Hashem would be a possible choice. She could undergo a cathartic release through Hashem especially that he proves to be a reliable person. But she gets him wrong and suspects all his motives. Because he views her as the only remaining link to his home country, Hashem feels the desire 'to touch her hands and face and the hem of her dress,' 18 to feel and smell Lebanon through her. He seems willing to support her and be the desired empathetic listener even when he realises that she is not a virgin. Hashem tries to know the truth to help Zahra marry the man she is supposed to be in love with and solve the problem, whatever it is. Ironically, fear from Hashem's scorn, anger, or silence is not the barrier to Zahra's confession. She remains silent simply because she does not want to let go of her traumatic past. Zahra could even have narrated her story to the sniper, especially that he has initiated verbal communication through his reverie about the past. Yet, silence was Zahra's only and typical response.

However, Zahra does attempt to counteract traumatic dissociation through the tactic of 'acting-out' that features behavioral re-enactment based on physical inscription. Critic Kolk demonstrates how trauma is usually repeated on 'behavioral, emotional, physiologic, and neuroendocrinologic levels.' 19 As such, people who undergo a trauma 'have a tendency to relive the past, to exist in the present as if they were still fully in the past, with no distance from it.' 20 LaCapra directly relates such repetition compulsion to the process of 'acting-out'. In alShaykh's narrative, Zahra attempts to transform this repetition into a tactic of resistance to trauma. She practices behavioral re-enactment by playing with her pimples. Such act represents a physical re-inscription of the painful past on her face. So, Zahra's behavioral re-enactment of her childhood's trauma develops into bodily disfigurement and self-mutilation. On the other hand, Zahra continuously relives iconic memories of her mother's liaison affair by maintaining a sexual intercourse with the disgusting Malek. Her body 'never once responded to his or Post-Traumatic Responses in the War Narratives

222

experienced ecstasy.'21 Still, she never rejects his invitations and keeps seeing him even after her painful abortion. In psychoanalysis, this kind of reaction falls under the turning-against-the-self defense mechanism. Such tactic is defined as 'the turning back upon the self of an impulse directed against an object' and as 'displacement onto one's self.' 22 This displacement becomes Zahra's alternative and subversive target. But she harms herself instead of harming others.

Consequently, destructive rather than therapeutic reenactment is established. 
Reading both narratives suggests that it is the 'working-through' strategy that transforms the female victims into fully powerful 'ethical agent[s]' 23 and exposes the limitation of the 'acting out'. In Adichie's narrative, both Olanna and Kainene manage to generate a 'countervailing force' that helps them survive and be engaged in the external world again. Seeking to make a change and help the community around, the two females play complementary roles each from her own experience and career. While Olanna, as a professor, works on the pedagogical aspect, Kainene works on the economic side. After Akwakuma Primary School is turned into a refugee camp, Olanna organizes classes in the yard. With the help of a friend, Professor Achara, she manages to get some books, benches, and blackboards. Olanna starts to teach mathematics, English, civics, as well as ideals of the Biafran cause. Believing that they can make a difference, Kainene decides that they have to create their own income. She works as a food supplier for the refugee camp, and starts a farm at the camp to grow their own protein, soya beans, and akidi. She decides to bring a man from Enugu who has a fantastic talent for making baskets and lamps to teach the others, and asks the Red Cross to send them a doctor every week. In al-Shaykh's narrative, Zahra devotes herself toward ending the war.24 She attempts to convince warriors of releasing their captives.25 She also undertakes a voluntary work at a hospital.26 She even decides to divert the sniper from using his rifle.27 However, all her attempts at peace and agency prove to be futile. Her cause particularly ends at the hands of the sniper, with whom she falls in love, and by his death machine.

\section{Conclusion}

As war narratives, both Story of Zahra and Half of a Yellow Sun readdress female non-combatants' victimisation and articulate their varied attempts at healing and agency in the Middle Eastern and African contexts. The paratexts of al-Shaykh's narrative renounce the possibility of any active role for traumatised female victims in collective change. However, reading al-Shaykh's narrative in light of Adichie's reveals Zahra's attempted but limited agency compared with Olanna's productive agency. As such, Adichie's narrative revises the definition of victimhood, opening up a space for potential involvement of the traumatised victim in social change.

Majda R. Atieh and Ghada Mohammad

\section{3}

\section{Notes}

1 Bessel Van der Kolk, 'The Compulsion to Repeat the Trauma: Re-Enactment, Revictimization, and Masochism', Psychiatric Clinics of North America 12 (1989): 389-411.

2 Hanan Al-Shaykh, The Story of Zahra, trans. Peter Ford (New York: Anchor, 1995), 3 .

3 Dori Laub and Shoshana Felman, Testimony: Crisis of Witnessing in Literature, Psychoanalysis, and History (New York: Routledge, 1992), 63.

4 Al-Shaykh, Story of Zahra, 34-35.

5 George F. Rhoades and Vedat Sar, eds., Trauma and Dissociation in a CrossCultural Perspective: Not Just a North American Phenomenon (Binghamton: Haworth Press, 2005), 22.

6 Dominick LaCapra, "“Acting-Out" and "Working-Through" Trauma', Shoah Research Center (New York: Cornell University, 1998), 4, accessed April 28, 2011. http://www1.yadvashem.org/odot_pdf/Microsoft\%20Word\%20-\%203646.pdf. 7 Ibid.

8 Ibid., 2.

9 Ibid.

10 Judith Lewis Herman, Trauma and Recovery (New York: Basic Books, 1992), 83. 
11 Adichie, Half of a Yellow Sun, 156.

12 Laub, Testimony, 68.

13 Suzette Henke, Shattered Subjects: Trauma and Testimony in Women's Life

Writing (New York: St. Martin’s, 2000), xxi.

14 Ibid., Xvi.

15 Ibid.

16 Adichie, Half of a Yellow Sun, 410.

17 Dori Laub, 'Truth and Testimony: The Process and the Struggle', in Trauma:

Explorations in Memory, ed. Cathy Caruth (Baltimore: John Hopkins University

Press, 1995), 61-75.

18 Al-Shaykh, Story of Zahra, 69.

${ }_{19}$ Van der Kolk, 'The Compulsion to Repeat the Trauma', 389-411.

20 Ibid., 2.

21 Al-Shaykh, Story of Zahra, 30.

${ }_{22}$ G. L. Bibring et al., 'A Study of the Psychological Processes in Pregnancy and of the Earliest Mother-child Relationship-II. Methodological Considerations',

Psychoanalytic Study of the Child 16 (1961): 25-72.

23 LaCapra, Trauma, 3.

24 Al-Shaykh, Story of Zahra, 135.

Post-Traumatic Responses in the War Narratives

224

25 Ibid., 133.

26 Ibid., 134.

27 Ibid., 157.

\section{Bibliography}

Adichie, Chimamanda Ngozi. Half of a Yellow Sun. New York: Knopf, 2006. Al-Shaykh, Hanan. The Story of Zahra. Translated by Peter Ford. New York: Anchor, 1995.

Bibring, G. L., T. F. Dwyer, D. S. Huntington, and A. Valenstein. 'A Study of the Psychological Processes in Pregnancy and of the Earliest Mother-child

Relationship-II. Methodological Considerations'. In Psychoanalytic Study of the Child 16 (1961): 25-72.

Henke, Suzette. Shattered Subjects: Trauma and Testimony in Women's Life

Writing. New York: St. Martin's, 2000.

Herman, Judith Lewis. Trauma and Recovery. New York: Basic Books, 1992.

Laub, Dori, and Shoshana Felman. Testimony: Crisis of Witnessing in Literature, Psychoanalysis, and History. New York: Routledge, 1992.

Laub, Dori. 'Truth and Testimony: The Process and the Struggle'. In Trauma:

Explorations in Memory, edited by Cathy Caruth, 61-75. Baltimore: John Hopkins University Press, 1995.

LaCapra, Dominick. "“Acting-Out" and "Working-Through" Trauma'. Shoah Research Center. New York: Cornell University, 1998. Accessed April 28, 2011. http://www1.yadvashem.org/odot_pdf/Microsoft\%20Word\%20-\%203646.pdf. Rhoades, George F., and Vedat Sar, eds. Trauma and Dissociation in a CrossCultural Perspective: Not Just a North American Phenomenon. Binghamton: Haworth Press, 2005.

Van der Kolk, Bessel. 'The Compulsion to Repeat the Trauma: Re-Enactment, Revictimization, and Masochism', Psychiatric Clinics of North America 12 (1989): 389-411.

Majda R. Atieh and Ghada Mohammad

225

Majda R. Atieh is a lecturer at Damascus University (Syria) and a Fulbright scholar affiliated with Howard University (USA). Her current research and teaching interests focus on postcolonial studies, women's writings of the black 
diaspora, and food pathology studies. Atieh has published on the celebratory resistance writings of Toni Morrison and other African American women writers in refereed journals and edited collections, including MELUS (2011), Tishreen University Journal $(2011,2012)$, and Contemporary African American Fiction: New Critical Essays (2009).

Ghada Mohammad is a Master's candidate at Damascus University (Syria). Her research interest is focused on the cultural construction of the war narrative. 